\title{
Deciphering Imidazoline Off-Targets by Fishing in the Class A of GPCR field
}

\section{Djikic, Teodora}

2020-07

Djikic , T , Vucicevic , J , Laurila , J , Radi , M , Veljkovic , N , Xhaard, H \& Nikolic , K M 2020 , ' Deciphering Imidazoline Off-Targets by Fishing in the Class A of GPCR field ' , Molecular informatics , vol. 39 , no. 7 , 1900165 . https://doi.org/10.1002/minf.201900165

http://hdl.handle.net/10138/326822

https://doi.org/10.1002/minf.201900165

unspecified

acceptedVersion

Downloaded from Helda, University of Helsinki institutional repository.

This is an electronic reprint of the original article.

This reprint may differ from the original in pagination and typographic detail.

Please cite the original version. 


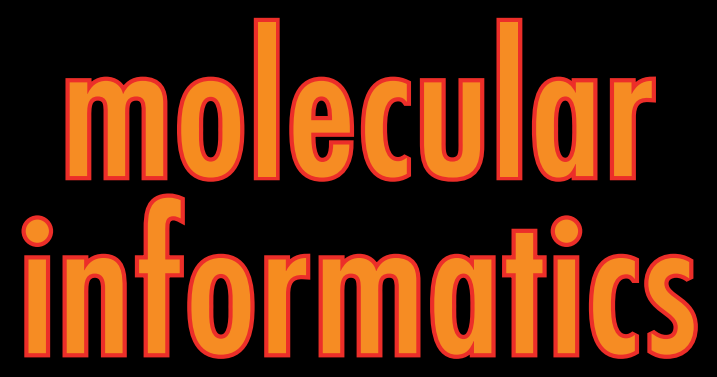

models - molecules - systems

\section{Accepted Article}

Title: Deciphering Imidazoline Off-Targets by Fishing in the Class A of GPCR field

Authors: Teodora Djikic, Jelica Vucicevic, Jonne Laurila, Marco Radi, Nevena Veljkovic, Henri Xhaard, and Katarina M. Nikolic

This manuscript has been accepted after peer review and appears as an Accepted Article online prior to editing, proofing, and formal publication of the final Version of Record (VoR). This work is currently citable by using the Digital Object Identifier (DOI) given below. The VoR will be published online in Early View as soon as possible and may be different to this Accepted Article as a result of editing. Readers should obtain the VoR from the journal website shown below when it is published to ensure accuracy of information. The authors are responsible for the content of this Accepted Article.

To be cited as: Mol. Inf. 10.1002/minf.201900165

Link to VoR: http://dx.doi.org/10.1002/minf.201900165 


\section{Deciphering Imidazoline Off-Targets by Fishing in the Class A of GPCR field}

Teodora Djikic ${ }^{[a]}$, Jelica Vucicevic ${ }^{[a]}$, Jonne Laurila[b], Marco Radi[c], Nevena Veljkovic ${ }^{[d]}$, Henri Xhaard[e] and Katarina Nikolic*[a]

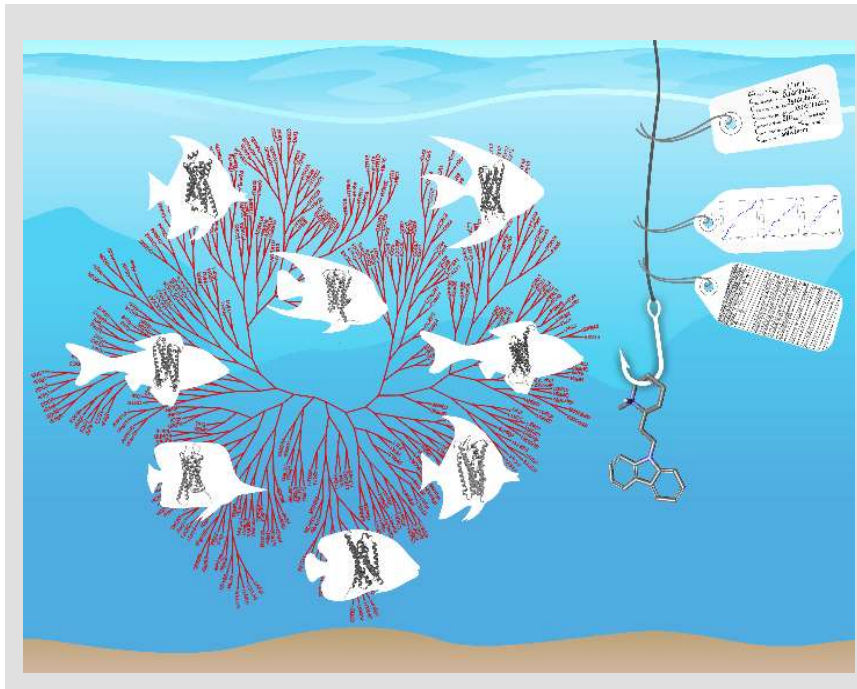

Keywords: off-target, target fishing, reverse docking, GPCRs, imidazolines
Abstract: Based on the finding that a central antihypertensive agent with high affinity for 11-type imidazoline receptors - rilmenidine, shows cytotoxic effects on cultured cancer cell lines, it has been suggested that imidazoline receptors agonists might have a therapeutic potential in the cancer therapy. Nevertheless, potential rilmenidine side effects caused by activation of a-adrenoceptors, or other associated receptors and enzymes, might hinder its therapeutic benefits. Considering that human $\alpha$-adrenoceptors belong to the rhodopsin-like class A of G-protein-coupled receptors (GPCRs) it is reasonable to assume that imidazolines might have the affinity for other receptors from the same class. Therefore, to investigate possible off-target effects of imidazoline ligands we have prepared a reverse docking protocol on class A GPCRs, using imidazoline ligands and their decoys. To verify our in silico results, three ligands with high scores and three ligands with low scores were tested for antagonistic activity on $a_{2^{-}}$ adrenoceptors. 
Running title

\section{Introduction}

Centrally acting hypotensive imidazoline derivatives, such as clonidine, rilmenidine and moxonidine, produce their activity through activation of $\alpha_{2}$-adrenoceptors and 11imidazoline receptors (I1-IR). ${ }^{1-4}$ Clonidine acts as an agonist of both receptors, whereas the new generation antihypertensive agents moxonidine and rilmenidine have more affinity towards I1-IR receptors and show less side effects than clonidine. ${ }^{5}$ Recently, it has been found that imidazoline derivatives have other important biological effects, not related to cardiovascular regulation, such as control of apoptosis and cell proliferation. ${ }^{6}$ Previously, we have demonstrated that rilmenidine induces apoptosis through deactivation of the Ras/MAP kinases ERK, p38 and JNK thus exhibiting proapoptotic and antiproliferative effects in cultured human leukemic K562 cells. ${ }^{7}$ Unfortunately, due to its pharmacological effects resulting also from $\alpha_{2}$-adrenoceptor activation, rilmenidine cannot be considered a suitable anticancer drug candidate. Therefore, we have designed and identified several rilmenidine derivatives with anticancer potential and without an agonistic activity on $\alpha_{2}$ - adrenoceptor. The carbazole $\mathbf{5 a}$, shown in Figure 1 resulted the most promising candidate. Moreover, the structure of compound $\mathbf{5 a}$ is similar to the structure of tricyclic antidepressants, which are known to have good affinities towards amine GPCRs in general. $^{8}$

The structure of $I_{1}-I R$ protein (Uniprot code Q9Y2I1) has not been solved to date. Since $\alpha_{2}$-adrenoceptor and monoamine oxidase are known to bind imidazolines, it was thought that I1IR might be structurally similar to these proteins. ${ }^{9}$ Several experimental studies have suggested that $I_{1}$ imidazoline sites might be coupled to a G-protein and might therefore also belong to the superfamily of G-protein-coupled receptors. ${ }^{10,11}$ However, by cloning, imidazoline receptor antisera-selected IRAS gene was discovered, and the similarity between $I_{1}-I R$ and $\alpha_{2}$-adrenoceptor or monoamine oxidase was not found. ${ }^{9}$ I1-IR possesses several domains involved in protein-protein interaction. It is attached to the plasma membrane by a phosphoinositide-3-phosphate-binding domain in its $\mathrm{N}$ terminus region - phox homology domain, and by the a5 subunit of the fibronectin receptor. ${ }^{12-15}$ Activation of $G$ proteins due to binding imidazoline compounds to $I_{1}-I R$ proteins might be caused by the sensitivity of the imidazoline-specific binding to GTP or its analogues ${ }^{10,16-19}$ Additionally, effects of imidazoline ligands on classical second messenger systems of $\mathrm{G}$ protein-coupled receptors (cAMP or inositol-phosphates and diacylglycerol-DAG) have been noticed in other animal models. ${ }^{20}$

GPCRs have 7 TM (seven transmembrane) domains connected by three extracellular and intracellular loops and share a small-molecule binding site located in the outer part of 7 TM domain. There are 6 classes within GPCR superfamily (A, B, C, F and Taste). Even though a similarly positioned pockets exist in classes $\mathrm{B}, \mathrm{C}$ and $\mathrm{F}$ and they share conserved fold with $7 \mathrm{TM}$, their binding sites are positioned in a different way to class $A .{ }^{21,22}$ In addition to the binding site location, the GPCRs from class A also have some binding site similarities. For example, aspartic acid at the position 3.32 is fully conserved in biogenic amine receptors, and it forms the salt bridge with positively charged nitrogen of ligand. Since imidazoline derivatives are positively charged on the physiological $\mathrm{pH} 7.4$, we might assume that they could form a salt bridge with aspartic acid residue (or other negatively charged amino acid residues near the binding pocket) of GPCRs. Taking into consideration all abovementioned, it was reasonable to assume that imidazoline derivatives might also show affinity towards other members of rhodopsin-like (class decided to analyze the affinity of our imidazoline derivatives on class A GPCRs in search for potential off-target effects.<smiles>Clc1cccc(Cl)c1NC1=NCCN1</smiles>

Clonidine<smiles>c1ccc2c(c1)OCC(C1=NCCN1)O2</smiles>

Idazoxan

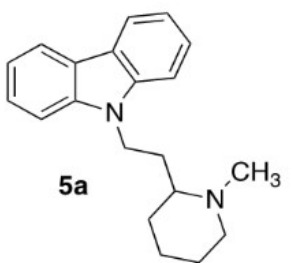<smiles>CC(Oc1c(Cl)cccc1Cl)C1=NCCN1</smiles>

Lofexidine<smiles>CC[C@@]1(C2=NCCN2)Cc2ccccc2O1</smiles>

Efaroxan

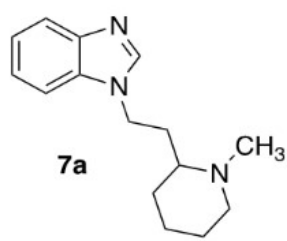

Figure 1. 2D structures of imidazoline compounds with different activity on $\alpha_{2-}$ adrenoceptors. Clonidine and lofexidine are agonists of $\alpha_{2}$-adrenoceptors idazoxan and efaroxan are antagonists, and $5 \mathrm{a}$ and $7 \mathrm{a}$ are newly synthesized compounds whose type of activity on $\alpha_{2}$ adrenergic receptors is yet to be determined.

In silico target fishing is a computational chemistry method that allows prediction of novel biological targets for small molecules. ${ }^{23,24}$ There are four main approaches: chemical similarity search, data-mining, bioactivity spectra and reverse docking. ${ }^{23}$ Unlike the first three approaches, which are ligand based, reverse docking relies on the 3D structure of target protein and provides insight into receptor-ligand binding that might help further optimization and modification of the lead compound. ${ }^{25}$ So far, several successful stories have been published that have used this approach for the off-target identification. ${ }^{26,27}$ One of the first applications of reverse docking protocol was for identification of targets for natural products. ${ }^{28-30}$ However, there are some limitations and several issues that are related to reverse docking methods, for example, target structure dataset construction problem, and inability to include receptor flexibility due to high computational cost. ${ }^{31}$

[a] Department of Pharmaceutical Chemistry, Faculty of PharmacyUniversity of Belgrade, Vojvode Stepe 450 11000 Belgrade, Serbia, e-mail: teodora.djikic@pharmacy.bg.ac.rs katarina.nikolic@pharmacy.bg.ac.rs

[b] Research Center for Integrative Physiology and Pharmacology, Institute of Biomedicine, University of Turku, Fl-20014 Turun yliopisto, Turku, Finland

[c] Dipartimento di Scienze degli Alimenti e del Farmaco, Università degli Studi di Parma, Viale delle Scienze, 27/A, 43124 Parma, Italy

[d] Laboratory for bioinformatics and computational chemistry, Institute of Nuclear Sciences Vinca, University of Belgrade, Mihaila Petrovica Alasa 14, 11001 Belgrade, Serbia

[e] Division of Pharmaceutical Chemistry, Drug Research Program, Division of Pharmaceutical Chemistry and Technology, Faculty of Pharmacy, University of Helsinki, P.O. Box 56, Fl-00014 University of Helsinki, Helsinki, Finland

Supporting Information for this article is available on the WWW under www. molinf.com 
GPCR structure dynamically fluctuates between different conformational states, stabilized by partial agonists, full agonists, antagonists and inverse agonists. Structural differences between active and inactive state are large at the binding site of the $\mathrm{G}$ protein: transmembrane domains TM 5 and TM 6 move out by $10-14 \AA$ to open the cavity. Additionally, there is a $2 \AA$ inward movement of the binding site and a slight $1 \AA$ upward movement of TM $3 .^{21}$ Accordingly, the protocol intended to be used for identification of agonists, partial agonists and antagonists should use active, intermediate and inactive 3D structures, respectively. The majority of GPCRs that have been crystalized so far, were crystalized in antagonist-bound, inactive conformation. Crystallization in active state is more challenging, and the number of available active $3 D$ structures is significantly smaller. The only X-ray structure of fully activated GPCR in complex with G protein published is $\beta_{2}$-adrenoceptor in complex with $G$ s protein. ${ }^{32} \mathrm{Up}$ to now, a number of $X$-ray structures of active states class $A$ GPCRs with engineered G-protein, G-protein mimetic, or a nanobodies were published: adenosine A2A receptor, ${ }^{33} \mu$ opioid receptor ${ }^{34}$, angiotensin II type 1 receptor ${ }^{35}$, etc. However, the number of available 3D inactive structures still remains significantly higher. Consequently, it is rational to assume that the homology models of inactive states GPCRs are more precise, and thus inactive conformations can be utilized with more confidence. Therefore, we have prepared the off-target screening protocol mostly using inactive structures.

In our previous work, several novel rilmenidine-derived compounds, lacking $\alpha_{2}$-adrenoceptor agonistic activity have been identified (e.g. 5a,7a Figure 1). ${ }^{8}$ Considering that human a-adrenoceptors belong to the rhodopsin-like class $A$ of GPCRs, it is reasonable to assume that these ligands might have the affinity for other receptors from the same class. Early identification of possible off-target effects could help us to select the best possible candidates for further studies. To investigate possible off-target effects of our candidates we have set-up a reverse docking protocol on 107 GPCRs, using 63 imidazoline ligands and their 670 decoys. Since the crystal structures all of receptors included were in their inactive state, this protocol may be suitable for identification of receptors antagonized by imidazoline ligands. To better assess the affinity of our candidates for chosen receptors, we compared docking scores of imidazolines and known antagonists. Finally, to verify our in silico results, three ligands with high scores and tree ligands with low scores were experimentally tested for antagonistic activity on $\alpha_{2}$-adrenoceptor.

\section{Materials and Methods}

\subsection{Virtual Target Screening (VTS)}

To identify interacting receptors (off-targets) for specific imidazoline ligands, a reverse docking study was performed. We have docked 63 imidazoline ligands ${ }^{8,36}$ (Supplementary Materials 1 - SM1) and 670 decoy into 107 GPCRs of rhodopsin-like family using Schrödinger software. ${ }^{37}$ Decoys were generated using DUD-E webserver (http://dude.docking.org/ ) $)^{38}$ and for each ligand roughly 10 decoys were selected. Decoys formation is based on similar physical properties but different chemical structure from ligands, and they are normally applied to validate the model. However, in our study the set of decoys was used to determine interacting receptors that bind imidazoline ligands better than decoys. Ligands and decoys were prepared using "LigPrep" protocol of Schrödinger suite, with OPLS3 (Optimized Potential for Liquid Simulations) force field ${ }^{39}$. Dominant forms at $\mathrm{pH}$ 6-8 were generated using Epik (Empirical pKa Prediction $)^{40}$ and stereoisomers with specified chirality were retained.

From the group of Class A Rhodopsin-like GPCRs, we have chosen 107 GPCRs for off-target study (27 X-ray structures and 80 homology models). 3D models for proteins with known $X$-ray structure were obtained from PDB database (https://www.rcsb.org/). It must be noted that new 3D models might have been published in the time window between writing and publishing this article. Homology models were downloaded from GPCR database (http://gpcrdb.org/ ). ${ }^{41}$ In order to obtain reliable results it is very important to define the correct binding site. Homology models were aligned with $\mathrm{X}$ ray structure of the same family using "Protein alignment" protocol in Schrödinger suite. For example, histamine receptors $\mathrm{H} 2, \mathrm{H} 3$ and $\mathrm{H} 4$ were aligned with crystal structure of histamine receptor $\mathrm{H} 1$, and so on. The coordinates of associated ligand from crystal structure (reference ligand) were taken as a centre of the binding pocket, and the same coordinates were used for homology models within the same family. ${ }^{42,43}$ In the case of $\alpha$-adrenoceptors, with no available corresponding crystal structure, the coordinates of aspartic acid D3.32 were used as a centre of the grid box. The outer grid box was set to be $20 \AA$, and inner grid box was set to be $10 \AA$ in all directions.

Receptors were cleaned, all the waters were removed and they were prepared using "Protein Preparation Wizard"44. They were optimized in OPLS3 ${ }^{39}$ force field by using $\mathrm{PROPKA}^{45}$ on $\mathrm{pH}=7$. Reverse docking was performed with XGlide $^{37}$ protocol with following parameters standard precision (SP), Ligand vdW scale factor: 0.80 , cutoff for a good RMSD 2.0 Á. Afterwards, docked compounds were ranked, based on SP scoring function ${ }^{37}$ - an empirical scoring function ${ }^{46}$ that approximates the ligand binding free energy (Equation 1.).

$$
\begin{aligned}
& \Delta G_{\text {bind }}=C_{\text {lipo-lipo }} \sum f\left(r_{l r}\right)+C_{\text {hbond-neut-ne }} \sum g(\Delta r) h(\Delta \alpha) \\
& +C_{\text {hbond-neut-ch }} \sum g(\Delta r) h(\Delta \alpha) \\
& +C_{\text {hbond-charged-charged }} \sum g(\Delta r) h(\Delta \alpha) \\
& +C_{\text {max-metal-ion }} \Sigma f\left(r_{\text {lm }}\right)+C_{\text {rotbHrotb }} \\
& +C_{\text {polar-phobVpolar-phob }}+C_{\text {coulEcoul }} \\
& +C_{\text {vdWEvdW }}+\text { solv.term }
\end{aligned}
$$

Equation 1: Free energy of binding $\left(\Delta G_{\text {bind }}\right)$ is the summation over all ligand-atom/receptor-atom pairs energies defined as lipophilic $\left(\mathrm{C}_{\text {lipo- }}\right.$ $\left.{ }_{\text {lipo }} \sum\left(r_{\mathrm{Ir}}\right)\right)$, all ligand-receptor hydrogen-bonding interactions - neutral and charged ( $C_{\text {hbond-neut-neut }} \sum \mathrm{g}(\Delta \mathrm{r}) \mathrm{h}(\Delta \alpha), \mathrm{C}_{\text {hbond-neut-charged }} \sum \mathrm{g}(\Delta \mathrm{r}) \mathrm{h}(\Delta \alpha)$, $\left.\mathrm{C}_{\text {hbond-charged-charged }} \sum \mathrm{g}(\Delta \mathrm{r}) \mathrm{h}(\Delta \alpha)\right)$, metal-ligand interaction term $\left(\mathrm{C}_{\max }\right.$ metal-ion $\left.\sum f\left(r_{l m}\right)\right)$, rotatable - $\left(C_{\text {rottrott }}\right)$, polar but non-hydrogen-bonding atom ( $C_{\text {polar-phobvpolar-phob }}$ ), contributions from the Coulomb and vdW interaction energies between the ligand and the receptor $\left(\mathrm{C}_{\text {coulEcoul }}+\right.$ $\mathrm{C}_{\mathrm{vdWEvaw}}$ ) and solvatation terms (calculated by docking of explicit water into the binding site for each competitive ligand pose and measuring the exposure of various groups to it), where $r$ represents the atomic distance, while $f, g$, and $h$ are functions that give a full score (1.00) for distances or angles that lie within nominal limits and a partial score $(1.00-0.00)$ for distances or angles that lie outside those limits but inside larger threshold values. ${ }^{37}$

\subsection{Off-target receptor selection}

Obtained reverse docking results were further used to create Receiver Operating Characteristic (ROC) curves. Subsequently, Area Under the Curve (AUC) as well as early Enrichment Factor on $1 \%$ and $10 \%$ (EF1, EF10), were calculated using Rocker (http://users.jyu.fi/ pentikai/rocker/ ). ROC curve is a graphical plot that illustrates the diagnostic ability of some binary classifier system. AUC value of a ROC curve gives the probability of detection. Enrichment factors can be calculated for the top $X \%$ of the results, (Equation 2). ${ }^{47}$ 


$$
E F x=\frac{\frac{\text { Ligs } X \%}{\text { MolsX\% }}}{\frac{\text { Ligs_all }}{\text { Mols_all }}}
$$

Equation 2: calculation of early enrichment factor $\left(E F_{X}\right)$ where LigsX\%, MolsX\%, Ligs all and Molsall are the number of the ligands in the top $\mathrm{X} \%$ of the screened compounds, the number of the molecules in the top $\mathrm{X} \%$ of the screened compounds, the total number of the screened ligands, and the total number of the screened molecules, respectively.

The ROC curve AUC value itself does not always straightforwardly provide detailed information about the early enrichment, but the visualization of its plot or calculation of the EF can give useful information about the enrichment of the active molecules. ROC AUC value reported together with early enrichment $(E F x)$ enables a realistic estimate about the capability of the classifier to separate active from inactives. ${ }^{47-}$ 49 This is usually employed for evaluation of Virtual Screening (VS) models, e.g. to check how well the model differentiates between active and inactive compounds. ${ }^{47}$ However, in our study, ROC and early enrichments were used to detect which GPCRs are more favoured by imidazoline ligands comparing to decoys.

\subsection{Validation of docking protocol using $\alpha_{2-}$ adrenoceptors}

To validate and decide on a correct protocol for further offtarget selection three compounds with high (efaroxan, idazoxan and 5a) and three compounds with low (clonidine, piodclonidine and lofexidine) predicted activity on all three subtypes of $\alpha_{2}$-adrenoceptor were selected. These ligands were docked into all three subtypes of $\alpha_{2}$-adrenoceptor along with known ligands of these receptors obtained from CHEMBL database (https://www.ebi.ac.uk/chembl/). Docking was performed in Schrodinger suite using two different scoring functions: standard precision (SP) and extra precision (XP). ${ }^{50}$ The XP scoring function (Equation 3.) does more extensive sampling than SP scoring function. It employs a more sophisticated scoring function, with greater requirements for ligand-receptor shape complementarity. This extensive XP procedure leads to lower number of false positives than SP Score. However, XP penalizes ligands that do not fit well to the exact receptor conformation used. Therefore, XP scoring function is recommended for docking to multiple receptor conformations..$^{50}$

$$
\begin{gathered}
\text { XP score }=E_{\text {coul }}+E_{\mathrm{vdw}}+E_{\text {bind }}+E_{\text {penalty }} \\
E_{\text {bind }}=E_{\text {hyd_enclosure }}+E_{\text {hb_nn_motif }}+E_{\text {hb_cc_motif }}+E_{p i} \\
+E_{\text {hb_pair }}+E_{\text {phobi _pair }} \\
E_{\text {penalty }}=E_{\text {desolv }}+E_{\text {lig_strain }}
\end{gathered}
$$

Equation 3: XP score represents a sum of Coulomb $\left(E_{\text {coul }}\right)$, van der Walls $\left(E_{v d w}\right)$ forces, binding energy ( $\left.E_{\text {bind }}\right)$ and energy penalty $\left(E_{\text {penalty }}\right)$. Binding energy is sum of improved energies of hydrophobic enclosure

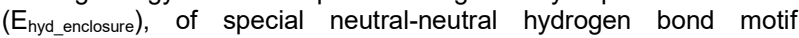
$\left(E_{n b \_n n \_m o t i f}\right)$, special charged-charged hydrogen bond motif ( $\left.E_{n b \_n n \_m o t i f}\right)$, hydrogen bond pair $\left(E_{h b \_p a i r}\right)$, lipophilic ligand atoms pair ( $E_{\text {phobic_pair }}$ ). Penalizing binding energy is a sum of desovatation penalties $\left(E_{\text {desolv }}\right)$ and contact penalties (Elig_strain $).{ }^{50}$

Since X-ray structures of $\alpha_{2}$-adrenoceptors have not been resolved yet, an in vitro study was performed for their validation. Accordingly, in addition to in silico studies, abovementioned six ligands were tested on their $\alpha_{2}$ adrenergic activity in vitro.

\subsection{Additional off-targets selection}

The off-target affinity profile of efaroxan, idazoxan and $\mathbf{5 a}$ was further evaluated on ten GPCRs, which were singled out as off-targets. In order to predict their binding affinity, we have compared their docking scores with the scores of known ligands of the chosen off-target receptors. Compounds were docked into selected receptors along with known ligands obtained from CHEMBL database (https://www.ebi.ac.uk/chembl/). ${ }^{51-57}$ Docking was performed in the same manner as mentioned in chapter 2.3, using two different scoring functions: standard precision (SP) and extra precision (XP). ${ }^{50}$

\subsection{Cell culture}

$\mathrm{CHO}$ cells stably expressing human $\alpha_{2 \mathrm{~A}}$-adrenoreceptors were cultured as described previously. ${ }^{58}$ Before the functional $\left[{ }^{35} \mathrm{~S}\right] \mathrm{GTPYS}$ binding assays, the cultured cells were tested for their capacity to bind the $\alpha_{2}-A R$ antagonist radioligand $\left[{ }^{3} \mathrm{H}\right] \mathrm{RS}-$ 79948-197 (GE Healthcare, London, UK). Confluent cells were harvested into chilled phosphate-buffered saline, pelleted and frozen at $-70^{\circ} \mathrm{C}$.

\subsection{Membrane preparation}

All procedures were performed on ice. $\mathrm{CHO}$ cell pellets were thawed and suspended in hypotonic lysis buffer (10 mM Tris$\mathrm{HCl}, \quad 0.1 \mathrm{mM}$ EDTA, $0.32 \mathrm{mM}$ sucrose, $\mathrm{pH}$ 7.4) and homogenised using an Ultra-Turrax homogeniser $(3 \times 10 \mathrm{~s}$ at $8000 \mathrm{rpm})$. The homogenate was centrifuged at $180 \mathrm{~g}$ for 15 min to remove cell nuclei, unbroken cells and aggregates. The supernatants were pooled and centrifuged at 50,227 $\mathrm{g}$ for 30 min. The pellet was washed with TE buffer (10 mM Tris, 0.1 $\mathrm{mM}$ EDTA) and re-centrifugated as above. The membranes were then suspended in TE buffer, aliquoted and stored at $70{ }^{\circ} \mathrm{C}$ until used. Protein concentrations were determined with the method of Bradford using bovine serum albumin as reference. ${ }^{59}$

\section{$2.7\left[{ }^{35} \mathrm{~S}\right] \mathrm{GTPYS}$ binding assay}

Agonist-induced stimulation of $\left[{ }^{35} \mathrm{~S}\right] \mathrm{GTP} Y \mathrm{~S}$ binding was measured essentially as described previously. ${ }^{60}$ Briefly, membranes were thawed and diluted with binding buffer (25 $\mathrm{mM}$ Tris, $1 \mathrm{mM}$ EDTA, $5 \mathrm{mM} \mathrm{MgCl}_{2}, 20 \mathrm{mM} \mathrm{NaCl}, 1 \mu \mathrm{M}$ GDP, $1 \mathrm{mM}$ DTT, $30 \mu \mathrm{M}$ ascorbic acid, $\mathrm{pH}$ 7.4). Incubations were performed on 96-well Millipore MultiScreen MSFBN glassfibre filter plates. Samples containing $5 \mu \mathrm{g}$ of membrane protein were incubated with 7 or 8 serial dilutions of the test compounds and $0.1 \mathrm{nM}\left[{ }^{35} \mathrm{~S}\right] \mathrm{GTPYS}$. Reactions were terminated after 30 min incubation at RT by rapid vacuum filtration using a Millipore MultiScreen Vacuum Manifold. The filter plates were washed three times with ice-cold wash buffer (20 mM Tris, $1 \mathrm{mM}$ EDTA, $5 \mathrm{mM} \mathrm{MgCl}$, pH 7.4). Filters were dried and $50 \mu$ l SuperMix scintillation cocktail was added into each well. The incorporated radioactivity was measured using a MicroBeta2 microplate counter (PerkinElmer). All experiments were performed in duplicate and repeated at least three times. Analysis of the results with GraphPad Prism software yielded estimates of agonist potency $\left(E_{50}\right)$ and efficacy (intrinsic activity in comparison to the natural full agonist adrenaline).

\section{Results}

\subsection{Validation of reverse docking protocol}

Reverse docking was validated by analysing the score, rank and root mean square deviation (RMSD) from the reference ligands (Supplementary Materials 2. - SM2). As mentioned above, reference ligands were taken from the X-ray crystal structures. Most of the reference ligands were ranked among the top $1 \%$ of screened compounds for its receptor (majority was ranked $1^{\mathrm{st}}$ ), and had root mean square deviation (RMSD) from crystal structure of less than $2 \AA$. For the receptors whose crystal ligands did not rank in the first $1 \%$, additional interactions with water molecules or with adjuvant compounds used for the crystallization were noticed. Low ranking of 
Running title

reference ligand for chemokine $\mathrm{CxC}$ receptor 4 (PDB accession code: 3ODU) (antagonist IT1t which was ranked $55^{\text {th }}$ of all screened compounds), was due to the interaction of this ligand with 9 molecules of crystal water in the binding pocket. Furthermore, crystal ligand of neuropeptide receptor 1 - NP1 (PDB code: 5ZBH) had high docking score and was rank $1^{\text {st }}$ of all the screened compounds, but it had a large RMSD (12.7 $\AA$ ) most probably because of the numerous torsional angles of the ligand. Nonetheless, due to low ranking of reference ligand and/or large RMSD from crystal ligand, all the receptors from chemokine $\mathrm{CxC}$ motif and Neuropeptide receptor family were excluded. XGlide scores, rankings and RMSD values for reference ligands along with detailed analysis of binding modes of and protein-ligand interactions are shown in Supplementary Materials 2. - SM2.

\subsection{Off-target receptors selection}

For the selection of off-target receptors, ROC curves were created, and subsequently AUC and early Enrichment Factors (EF1\% and 10\%) were calculated. All the results are represented in Supplementary Materials 3 (SM3). For thirtytwo receptors, ROC curve AUC was larger or equal to 0.5 . The cut-off 0.5 for AUC which indicates that imidazoline ligands and decoys bind equally for the corresponding receptor. AUC larger than 0.5 means that imidazoline ligands are preferred by these 32 receptors over the respective decoys. These 32 receptors are potential off-targets for the examined imidazoline ligands (Table 1). However, as mentioned above, the ROC AUC value does not directly give detailed information about the early enrichment. ${ }^{47}$ If sole ROC AUC value were to be followed, we could have missed out interesting off-target GPCR receptors. However, early enrichment factor (EF10\%) suggests that there is a considerable number of ligands of interest in the first $10 \%$ of results. Therefore, we have ranked 32 candidate receptors based on EF10\% and selected twenty receptors with highest EF10\% as off-targets (Table 2).

Further, we have examined the literature in search of experimental results that would confirm our aforementioned findings. Majority of the in vitro studies for imidazoline ligands were carried out on imidazolines 11 receptors and $\alpha$ adrenoceptors, (mainly on $\alpha_{2}$-adrenoreceptors) while the information on imidazoline ligands binding other GPCRs is rather obscure. On the other hand, the X-ray structures for $\alpha$ adrenoceptors have not been published yet, and we did not have a reference ligand to use for the validation. We decided to validate them by comparing in silico and in vitro experimental results. In the Supplementary Materials 4 (SM4), we have compared the reverse docking scores and rankings of selected imidazoline ligands with the experimental results that we found in literature for $\alpha_{2}$-adrenoceptors (https://pubchem.ncbi.nlm.nih.gov/,

https://www.ebi.ac.uk/chembl/). According to SI4, $a_{2-}$ adrenoceptor antagonists: idazoxan ${ }^{61}$, benazoline, BDF $6143^{62}$, and efaroxan were listed in the first $30 \%$ of our screening results. Furthermore clonidine, moxonidine, lofexidine and p-iodclonidine were ranked low. These compounds also have the affinity for $\alpha_{2}$-adrenoceptors, but they are agonists, which could be presumably the reason they did not show good binding for the inactive conformation of $\alpha_{2^{-}}$ adrenoceptors. As we have already pointed out, inactive conformations of GPCRs was used, making this protocol more suitable for identification of antagonistic activity on off-target receptors. In addition to a-adrenoceptors, idazoxan was tested for antagonistic activity on dopaminergic receptors (https://pubchem.ncbi.nlm.nih.gov/bioassay/488981) as well as opioid $\mu$ receptor $^{63}$, and proved to be inactive. These receptors were not selected as potential off-targets by our protocol. Moreover, XGlide scores and rankings of idazoxan molecular

informatics

were low for dopamine D1, D2 and D3 receptors, which is in agreement with experimental results (Table 3 ).

Table 1. Selected GPCRs with $A U C \geq 0.5$ and enrichment factor (EF10\%)

\begin{tabular}{|c|c|c|}
\hline GPCRs & AUC & EF10\% \\
\hline Free fatty acid receptor 1 & 0.7 & 2.51 \\
\hline Sphigosine-1-phosphate receptor 5 & 0.66 & 2.35 \\
\hline Serotonin receptor $5-\mathrm{HT}_{5 \mathrm{~A}}$ & 0.64 & 2.49 \\
\hline Endothelin receptor A & 0.61 & 1.6 \\
\hline$\alpha_{2 \mathrm{~A}-\text {-adrenoceptor }}$ & 0.6 & 1.78 \\
\hline Serotonin receptor $5-\mathrm{HT}_{7}$ & 0.58 & 2.72 \\
\hline Dopamine D4 receptor & 0.58 & 2.45 \\
\hline Purinoreceptor P2Y6 & 0.58 & 1.73 \\
\hline Chemokine CC motif receptor 10 & 0.58 & 1.07 \\
\hline Serotonin receptor $5-\mathrm{HT}_{1 \mathrm{~B}}$ & 0.57 & 1.6 \\
\hline $\mathbf{\alpha}_{1 \mathrm{~A} \text {-adrenoceptor }}$ & 0.56 & 1.64 \\
\hline Sphingosine-1-phosphate receptor 4 & 0.56 & 1.57 \\
\hline$\alpha_{2 c}$-adrenoceptors & 0.56 & 1.3 \\
\hline Protease Activated receptor 1 & 0.56 & 1.28 \\
\hline Purinoreceptor P2Y1 & 0.56 & 1.1 \\
\hline$\alpha_{2 \mathrm{~B} \text {-adrenoceptor }}$ & 0.55 & 1.46 \\
\hline Purinoreceptor P2Y2 & 0.54 & 0.87 \\
\hline Endothelin receptor B & 0.53 & 1.28 \\
\hline Prostaglandin receptor E2 & 0.53 & 1.25 \\
\hline Serotonin receptor $5-\mathrm{HT}_{1 \mathrm{~F}}$ & 0.53 & 1.24 \\
\hline Serotonin receptor $5-\mathrm{HT}_{2 B}$ & 0.53 & 1.24 \\
\hline$\alpha_{1 \mathrm{~B}-\text {-adrenoceptor }}$ & 0.52 & 1.92 \\
\hline Adenosine $\mathrm{A} 1$ receptor & 0.52 & 1.75 \\
\hline Nociceptine/orfanin receptor & 0.52 & 1.66 \\
\hline Dopamine D5 receptor & 0.52 & 1.55 \\
\hline Lysophosphatidic acid receptor 5 & 0.51 & 1.4 \\
\hline Dopamine D1 receptor & 0.51 & 0.92 \\
\hline Serotonin receptor $5-\mathrm{HT}_{4}$ & 0.51 & 0.31 \\
\hline Serotonin receptor $5-\mathrm{HT}_{2 \mathrm{~A}}$ & 0.5 & 3.08 \\
\hline Purinoreceptor P2Y12 & 0.5 & 0.94 \\
\hline Lysophosphatidic acid receptor 3 & 0.5 & 0.79 \\
\hline Serotonin receptor $5-\mathrm{HT}_{1 \mathrm{~A}}$ & 0.5 & 0.79 \\
\hline
\end{tabular}

Table 2. 20 proteins, selected based on EF10\%, as potential offtargets of imidazoline ligands.

\begin{tabular}{|c|c|}
\hline GPCRs & EF10\% \\
\hline Serotonin receptor 5-HT2A & 3.08 \\
\hline Serotonin receptor 5-HT7 & 2.72 \\
\hline Free fatty acid receptor 1 & $\mathbf{2 . 5 1}$ \\
\hline Serotonin receptor 5-HT5A & 2.49 \\
\hline Dopamine D4 receptor & $\mathbf{2 . 4 5}$ \\
\hline Sphigosine-1-phosphate D5 receptor & 2.35 \\
\hline a 18 -adrenoceptor & 1.92 \\
\hline$\alpha_{2 \mathrm{~A}-\text {-adrenoceptor }}$ & 1.78 \\
\hline
\end{tabular}




\begin{tabular}{|c|c|}
\hline Adenosine A1 receptor & $\mathbf{1 . 7 6}$ \\
\hline Purinoreceptor P2Y6 & 1.73 \\
\hline Serotonin receptor 5-HT1 1b & $\mathbf{1 . 6 0}$ \\
\hline Nociceptine/orphanin receptor & $\mathbf{1 . 6 6}$ \\
\hline a1A-adrenoceptor & 1.64 \\
\hline Endothelin receptor A & 1.60 \\
\hline Sphigosine-1-phosphate receptor 4 & 1.57 \\
\hline dopamine D5 receptor & 1.55 \\
\hline a28-adrenoceptor & 1.46 \\
\hline Lysophosphatidic acid receptor 5 & 1.40 \\
\hline a2c-adrenoceptor & 1.30 \\
\hline Protease activated receptor 1 & $\mathbf{1 . 2 8}$ \\
\hline Endothelin receptor B & $\mathbf{1 . 2 8}$ \\
\hline
\end{tabular}

EC50 and efficacy (intrinsic activity in comparison to the natural full agonist adrenaline) in vitro for abovementioned receptors. Based on this, we may suggest that, if the compound has high values of both SP and XP score it is highly likely that it will show antagonistic activity in vitro.

Table 4. Comparison of in silico and in vitro results

Off-target proteins were selected based on EF ranked by the EF10\%, with AUC under the 5 and AUC ROC. X-ray structures are marked in bold; their reference ligand reverse docking score and rankings along with the root mean square deviation (RMSD) from the crystal ligand are presented. For homology models ligands from the receptor of the same subfamily were taken as reference ligands.

Table 3: Comparison of in silico results with in vitro results obtained from CHEMBL

\begin{tabular}{ccccccc}
\hline GPCR & Family & AUC & EF10\% & $\begin{array}{c}\text { XGlide } \\
\text { score }\end{array}$ & $\begin{array}{c}\text { XGlide } \\
\text { rank }\end{array}$ & activity \\
\hline $\begin{array}{c}\text { Dopamine D1 } \\
\text { receptor }\end{array}$ & Amine & 0.51 & 0.92 & -5.92 & 133 & IC50>1000 \\
$\begin{array}{c}\text { Dopamine D2 } \\
\text { receptor }\end{array}$ & Amine & 0.43 & 0.31 & -5.06 & 259 & IC50>1000 \\
$\begin{array}{c}\text { Dopamine D3 } \\
\text { receptor }\end{array}$ & Amine & 0.44 & 1.71 & -4.61 & 488 & IC50>1000 \\
$\begin{array}{c}\mu \text { Opioid } \\
\text { receptor }\end{array}$ & SOG & 0.47 & 1.07 & -4.56 & 97 & inactive \\
\hline
\end{tabular}

${ }^{*}$ ROC, EF10\%, reverse docking (XGlide) scores and rankings of idazoxan on dopaminergic D1, D2 and D3, and $\mu$ opioid receptors, and the comparison with experimental results. These results can represent a negative control- proteins that are not off-targets of idazoxan were not chosen by the protocol.

\subsection{Validation of docking protocol using $\alpha_{2-}$ adrenoceptors}

Six ligands (efaroxan, idazoxan, 5a, clonidine, p iodclonidine, and lofexidine) were selected for further testing on $\alpha_{2^{-}}$ adrenoceptors.

The docking results (SP and XP docking scores) of selected ligands in $\alpha_{2}$-adrenoceptors are shown in Table 4 . Docking scores of efaroxan, idazoxan and $\mathbf{5 a}$ were comparable with docking scores of known ligands for these receptors (Supplementary Materials 5 - SM5). Based on the SP and XP docking scores and their correlation with in vitro pKi values of known ligands, obtained from CHEMBL database, we concluded that SP scores had better correlation with experimental results. We might suggest that this is due to the $\mathrm{XP}$ scoring function, which has greater requirements for ligand-receptor shape complementarity and penalizes ligands that do not fit well to the exact receptor conformation used. Since we used only one receptor conformation obtained from GPCR database, SP scores were more relevant to follow. Therefore, based on SP score efaroxan, idazoxan and $\mathbf{5 a}$ were ranked high and clonidine, $\mathrm{p}$-iodclonidine and lofexidine were ranked low.

On the other hand, compounds $\mathbf{5 a}$ and efaroxan had high SP and XP scores for $\alpha_{2 A^{-}}$, and $\alpha_{2 B}$-adrenoceptors. In the same manner efaroxan and idazoxan scored highly with both scores for $\alpha_{2 c}$-adrenoceptor. These compounds also showed low

\begin{tabular}{|c|c|c|c|c|c|c|c|}
\hline \multicolumn{8}{|c|}{$\mathbf{a}_{2 \mathrm{~A}-\text {-adrenoceptor }}$} \\
\hline Compound & Type & pEC50 & $\begin{array}{l}\text { Intrinsic } \\
\text { activity }\end{array}$ & $\begin{array}{l}\text { XGlide } \\
\text { score }\end{array}$ & $\begin{array}{c}\text { XGlide } \\
\text { rank }\end{array}$ & $\begin{array}{l}\text { SP } \\
\text { score }\end{array}$ & $\underset{\text { score }}{\mathrm{XP}}$ \\
\hline Clonidine & Agonist & $\begin{array}{c}8,00 \pm \\
0,10\end{array}$ & $50 \pm 3$ & -4.06 & 667 & -4.65 & -7.32 \\
\hline Lofexidine & Agonist & $\begin{array}{c}8,39 \pm \\
0,24\end{array}$ & $23 \pm 4$ & -4.52 & 602 & -5.02 & -4.97 \\
\hline $\begin{array}{c}\mathrm{p}- \\
\text { lodclonidine }\end{array}$ & Agonist & $\begin{array}{c}8,80 \pm \\
0,24\end{array}$ & $46 \pm 3$ & -4.05 & 671 & -4.40 & -4.92 \\
\hline Efaroxan & Antagonist & n.d. & $0 \pm 1$ & -6.67 & 55 & -5.95 & -5.25 \\
\hline Idazoxan & Antagonist & n.d. & $0 \pm 3$ & -6.39 & 90 & -6.38 & -3.25 \\
\hline $5 a$ & & n.d. & $-1 \pm 2$ & -5.93 & 197 & -6.38 & -5.73 \\
\hline Adrenaline & & $\begin{array}{c}7,66 \pm \\
0,05\end{array}$ & 100 & & & & \\
\hline \multicolumn{8}{|c|}{$\mathbf{a}_{28 \text {-adrenoceptor }}$} \\
\hline Clonidine & Agonist & $\begin{array}{c}7,24 \pm \\
0,18\end{array}$ & $23 \pm 1$ & -4.69 & 627 & -4.79 & -4.97 \\
\hline Lofexidine & Agonist & $\begin{array}{c}7,21 \pm \\
0,02\end{array}$ & $59 \pm 3$ & -5.26 & 424 & -5.18 & -3.58 \\
\hline $\begin{array}{c}\text { p- } \\
\text { lodclonidine }\end{array}$ & Agonist & $\begin{array}{c}7,43 \pm \\
0,27\end{array}$ & $21 \pm 0$ & -4.31 & 635 & -4.71 & -4.96 \\
\hline Efaroxan & Antagonist & n.d. & $0 \pm 0$ & -6.91 & 61 & -5.71 & -6.28 \\
\hline Idazoxan & Antagonist & n.d. & $2 \pm 10$ & -6.68 & 98 & -6.33 & -6.62 \\
\hline $5 a$ & & $\begin{array}{c}4,87 \pm \\
0,21\end{array}$ & $12 \pm 6$ & -6.83 & 72 & -6.90 & -7.45 \\
\hline Adrenaline & & $\begin{array}{c}6,74 \pm \\
0,06\end{array}$ & 100 & & & & \\
\hline \multicolumn{8}{|c|}{$\mathbf{a}_{2 c}$-adrenoceptor } \\
\hline Clonidine & Agonist & $\begin{array}{c}6,15 \pm \\
0,07\end{array}$ & $3 \pm 1$ & -4.89 & 526 & -5.681 & -4.97 \\
\hline Lofexidine & Agonist & $\begin{array}{c}5,11 \pm \\
0,38\end{array}$ & $45 \pm 13$ & -5.26 & 424 & -5.207 & -5.78 \\
\hline $\begin{array}{c}\text { p- } \\
\text { lodclonidine }\end{array}$ & Agonist & $\begin{array}{c}6,33 \pm \\
1,04\end{array}$ & $13 \pm 9$ & -4.31 & 635 & -4.755 & -6.13 \\
\hline Efaroxan & Antagonist & n.d. & $1 \pm 3$ & -6.7 & 57 & -7.081 & -7.15 \\
\hline Idazoxan & Antagonist & $\begin{array}{c}3,80 \pm \\
0,23\end{array}$ & $4 \pm 2$ & -6.34 & 127 & -7 & -6.50 \\
\hline $5 a$ & & $\begin{array}{c}3,99 \pm \\
0,10\end{array}$ & $12 \pm 6$ & -6.41 & 110 & -6.59 & -5.0 \\
\hline Adrenaline & & $\begin{array}{c}6,26 \pm \\
0,49\end{array}$ & 100 & & & & \\
\hline $\begin{array}{l}\text { Correlation } \\
\text { with intrinsic } \\
\text { activity }\end{array}$ & & & & 0.651 & & 0.678 & 0.182 \\
\hline
\end{tabular}

${ }^{*}$ Intrinsic activity is represented as the \% of adrenaline. Antagonists had high docking score and were ranked in first $25 \%$ of screened ligands, while agonists had low docking scores and low ranking.

\subsection{Comparison of in silico and in vitro results}

As shown in Table 4, clonidine, efaroxan and $\mathbf{5 a}$, showed antagonistic activity on $\alpha_{2 A}$-adrenoceptors, in vitro. These three compounds had good reverse docking scores and they were ranked in the first $200(\sim 30 \%)$ of all the screened compounds. On the other hand, $\alpha_{2 A}$ agonists clonidine, lofexidine, and p-iodclonidine had low docking scores, and were ranked below 600 , which confirms that our model is suitable for identification of antagonists, but not agonists. Experimental results on $\alpha_{2 B}$ receptors were also in agreement with in silico results. The similar trend, as for $\alpha_{2 A}$ receptors, was noticed. Namely, 5a, efaroxan and idazoxan were ranked in the first 100 of the screened compounds and have showed antagonistic, or in case of $\mathbf{5 a}$ slight partial agonistic activity. On the other hand, clonidine, lofexidine and p-iodclonidine had stronger agonistic activity, and were ranked below 400 of the screened ligands. Moreover, according to in silico results 
Running title

efaroxan, idazoxan and $\mathbf{5 a}$ were ranked in the first $30 \%$ of screened compounds, and therefore chosen as $\alpha_{2 C}$ receptors antagonists. They did show antagonistic/slight partial agonistic activity in vitro. Furthermore, lofexidine which showed agonistic potential in vitro was ranked 424.

Unfortunately, in vitro results for clonidine and p-iodclonidine on $\alpha_{2 c}$ receptor were not totally in line with the in silico results. Their intrinsic activity towards the $\alpha_{2 c}$ was very weak in comparison to the $\alpha_{2 A}$ and $\alpha_{2 B}$-adrenoreceptor activity. Since they were ranked below 500 of screened compounds, we expected that they would show more agonistic activity. However, experimentally they showed only a very low partial agonistic activity, which did not fully agree with computational results.

Based on everything mentioned above, for the compounds in our set, we may conclude that Glide docking program combined with the SP scoring function is able to retrieve antagonist among the first $30 \%$ of compounds. On the other hand, full agonists have low docking scores and are ranked below 400/733 position. Accordingly, we have decided to use SP docking scores for selection of additional off-targets. Since, all the GPCRs models that were used were in their inactive conformation, we were able only to identify antagonists. Therefore, we may conclude, that the main shortcoming of this protocol is its inability to include receptor flexibility, due to the high computational cost. On the other hand, this model has the ability to differentiate between antagonists from agonists.

3.5 Additional Off-targets for efaroxan, idazoxan and $5 \mathrm{a}$ Along with $\mathrm{a}_{2}$-adrenoceptors, efaroxan, idazoxan and $\mathbf{5 a}$ were ranked in first $30 \%$ for several other GPCRs. Receptors shown in Table 5 might be interesting targets for these three ligands. To further evaluate obtained results we have docked selected imidazoline ligands and known active ligands to each off-target receptor and compared the results to single out receptors that are real off-targets for respective ligands. Whenever SP docking scores of efaroxan, idazoxan and $\mathbf{5 a}$ were comparable with known active compounds' scores it was marked as potentially active, whereas compounds with SP scores lower than the lowest score of known compounds were rejected. All the results are represented in Supplementary Materials 6 (SM6). Off-target receptors that were selected based on SP docking scores and ranking among the known ligands are represented in Table 6 .

Additionally, we have examined CHEMBL database for experimental confirmation of in silico results. We were able to find that idazoxan and efaroxan, which were chosen by our off-target protocol, do have antagonistic effect on $\alpha_{1}$ adrenoreceptors. For other GPCRs there were no experimental data. Therefore, by continuing our studies, we will perform additional in vitro testing on these targets. Results of this study might be useful for understanding potential side effects and/or finding novel indications of these imidazoline ligands.

Furthermore, it is known that all of the GPCRs from biogenic amines family have negatively charged aspartic acid D3.32 in the binding pocket, which is involved in important electrostatic interactions with positively charged ligands. We have assumed that negatively charged amino acid residues, near the binding pocket, could form the salt bridge with positively charged imidazoline ligands. Our analysis of reverse docking results have confirmed this assumption (Figures 2 and 3). Moreover, from Table 5 it can be observed that the majority of chosen off-target receptors for imidazoline ligands are biogenic amines receptors (adrenergic, dopaminergic and serotonergic). They all have the conserved aspartic acid at the 3.32 position and form the salt bridge with positively charged imidazoline ligands, as shown in Figures 2 and 3. molecular informatics
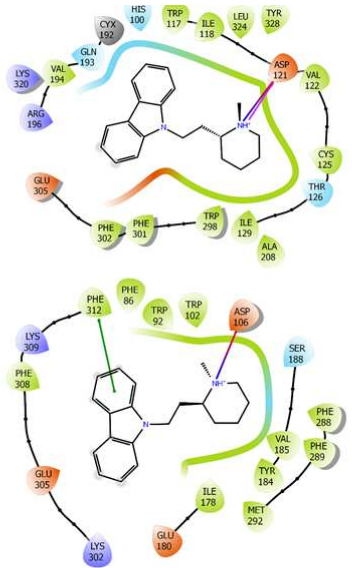

c

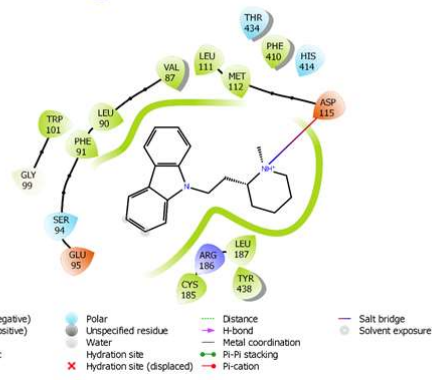

Figure 2. Interactions of 5 a compound with selected biogenic amines receptors. Positively charged amine of imidazoline is building the salt bridge with the aspartic acid on the position D3.32 of biogenic amine receptors: A) Serotonin 5-HT5A in complex, B) $\alpha_{1 A}$-adrenoceptors and C) Dopamine D4 receptor.
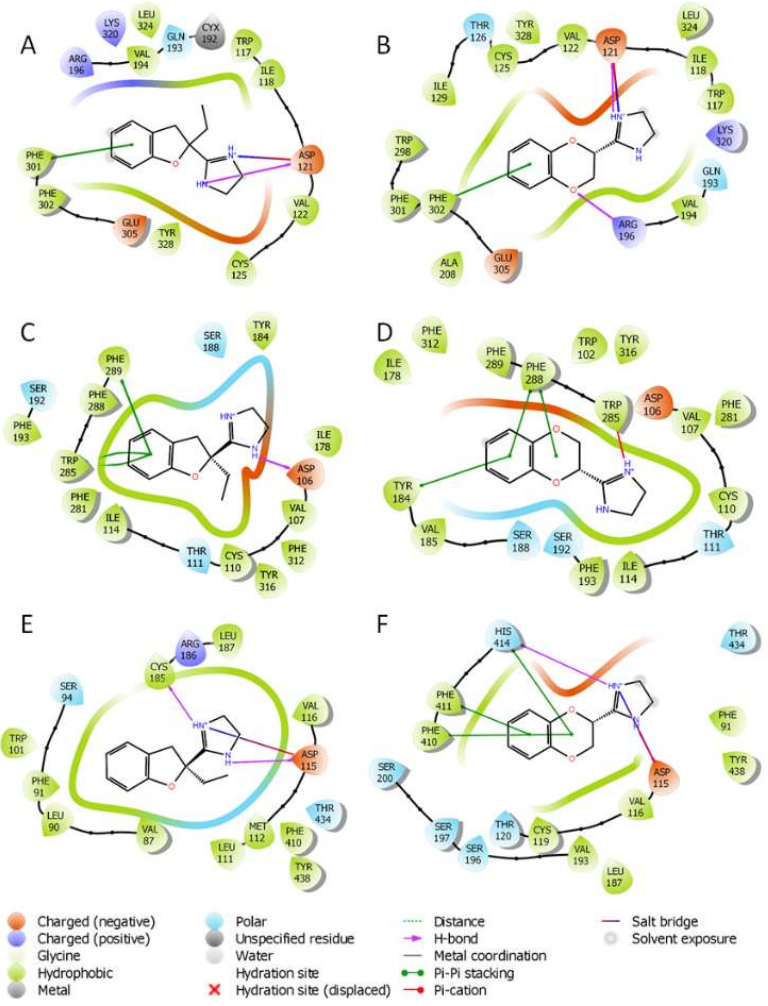

$\mathrm{F}$

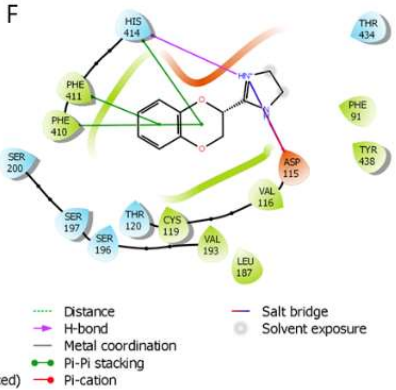

Figure 3. Interactions of efaroxan and idazoxan with selected biogenic amines receptors. Positively charged amine of imidazoline is building the salt bridge with the aspartic acid on the position D3.32 of biogenic amine receptors. Serotonin 5-HT5A in complex with A) efaroxan, and $B$ ) idazoxan; $\alpha_{1 A}$-adrenoceptors in complex with $C$ )

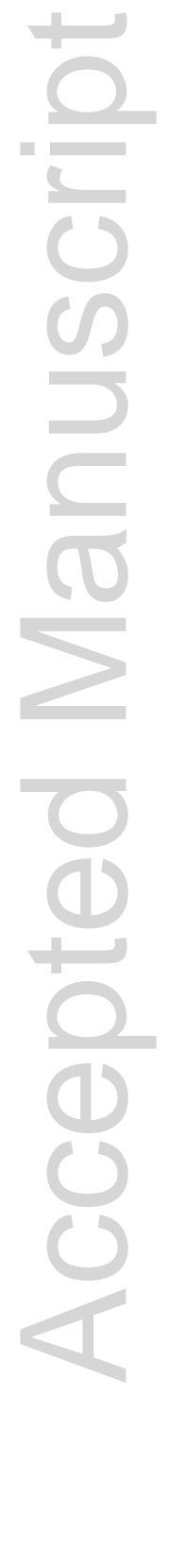


efaroxan, and D) idazoxan; Dopamine D4 receptor in complex with E) efaroxan, and F) idazoxan.

Table 5: Possible additional off-targets for $5 a$, efaroxan and idazoxan.

\begin{tabular}{|c|c|c|c|c|}
\hline compound & GPCRs & Family & $\begin{array}{l}\text { XGlide } \\
\text { score }\end{array}$ & rank \\
\hline \multirow{12}{*}{$5 a$} & Serotonin receptor $5-\mathrm{HT}_{1 \mathrm{~B}}$ & Amine & -6.68 & 22 \\
\hline & Serotonin receptor $5-\mathrm{HT}_{2 \mathrm{~A}}$ & Amine & -6.9 & 18 \\
\hline & Serotonin receptor $5-\mathrm{HT}_{7}$ & Amine & -6.69 & 30 \\
\hline & Adenosine receptor $\mathrm{A} 1$ & Amine & -7.48 & 58 \\
\hline & 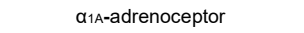 & Amine & -6.58 & 100 \\
\hline & $\alpha_{2 A}$-adrenoceptor & Amine & -5.93 & 197 \\
\hline & $\alpha_{2 B}$-adrenoceptor & Amine & -6.83 & 72 \\
\hline & $\alpha_{2 c}$-adrenoceptor & Amine & -6.41 & 110 \\
\hline & Dopamine D4 receptor & Amine & -6.46 & 139 \\
\hline & Dopamine D5 receptor & Amine & -7.05 & 12 \\
\hline & Lysophosphatidic acid receptor 5 & MECA & -6.55 & 42 \\
\hline & Protease activated receptor 1 & Purine & -8.49 & 44 \\
\hline \multirow{9}{*}{ EFAROXAN } & Adenozin A1 receptor & Amine & -6.96 & 157 \\
\hline & $\mathbf{\alpha}_{1 \mathrm{~A}-\text {-adrenoceptor }}$ & Amine & -6.37 & 147 \\
\hline & $\alpha_{2 B}$-adrenoceptor & Amine & -6.67 & 55 \\
\hline & $\alpha_{2 B}$-adrenoceptor & Amine & -6.91 & 61 \\
\hline & $\alpha_{2 C}$-adrenoceptor & Amine & -6.7 & 57 \\
\hline & Dopamine D4 receptor & Amine & -6.88 & 56 \\
\hline & Nociceptine/orphanin receptor & SOG & -6.12 & 47 \\
\hline & Protease activated receptor 1 & Purine & -7.88 & 96 \\
\hline & $\begin{array}{c}\text { Sphigosine-1-phosphate receptor } \\
4\end{array}$ & MECA & -5.5 & 168 \\
\hline \multirow{13}{*}{ IDAZOXAN } & Serotonin receptor $5-\mathrm{HT}_{5 \mathrm{~A}}$ & Amine & -6.01 & 29 \\
\hline & Serotonin receptor $5-\mathrm{HT}_{7}$ & Amine & -6.24 & 74 \\
\hline & $\alpha_{1 A}$-adrenoceptor & Amine & -6.3 & 173 \\
\hline & $\boldsymbol{\alpha}_{1 \mathrm{~B}-\text {-adrenoceptor }}$ & Amine & -6.56 & 59 \\
\hline & $\alpha_{2 A-a d r e n o c e p t o r}$ & Amine & -6.7 & 57 \\
\hline & $\alpha_{2 B}$-adrenoceptor & Amine & -6.68 & 98 \\
\hline & $\alpha_{2 c}$-adrenoceptor & Amine & -6.34 & 127 \\
\hline & Free fatty acid receptor 1 & Purine & -7.14 & 63 \\
\hline & Lysophosphatidic acid receptor 5 & Purine & -6.5 & 82 \\
\hline & Nociceptine/orphanin receptor & SOG & -5.59 & 74 \\
\hline & Purinoreceptor P2Y6 & Purine & -4.88 & 73 \\
\hline & Protease activating receptor 1 & Peptide & -7.24 & 177 \\
\hline & $\begin{array}{l}\text { Sphingosine-1-phosphate } \\
\text { receptor } 5\end{array}$ & MECA & -6.06 & 19 \\
\hline
\end{tabular}

Table 6: Selected off-target proteins for efaroxan, idazoxan and $5 a$.

\begin{tabular}{ccc}
\hline off-target GPCR & Family & compounds \\
\hline Serotonin receptor 5-HT1B & Amine & idazoxan, $\mathbf{5 a}$ \\
Serotonin receptor $5-\mathrm{HT}_{2 \mathrm{~A}}$ & Amine & idazoxan, $\mathbf{5 a}$ \\
Serotonin receptor $5-\mathrm{HT}_{5 \mathrm{~A}}$ & Amine & idazoxan, $\mathbf{5 a}$, efaroxan \\
Serotonin receptor 5-HT7 & Amine & idazoxan, $\mathbf{5 a}$ \\
Adenosine receptor A1 & MECA & $\mathbf{5 a}$ \\
$\mathbf{a}_{1 \mathrm{~A}-\text {-adrenoceptor }}$ & Amine & idazoxan, $\mathbf{5 a}$, efaroxan \\
$\mathbf{\alpha}_{1 \mathrm{~B}-\text {-adrenoceptor }}$ & Amine & idazoxan, $\mathbf{5 a}$, efaroxan
\end{tabular}

\begin{tabular}{ccc} 
Dopamine receptor D4 & Amine & idazoxan, 5a, efaroxan \\
Dopamine receptor D5 & Amine & efaroxan, 5a \\
Nociceptine/orphanin receptor & SOG & $/$ \\
\hline
\end{tabular}

\section{Discussion}

Using virtual target screening protocol, we have identified several GPCRs that might be antagonized by three selected imidazoline ligands: efaroxan, idazoxan and $5 \mathrm{a}$. The usage of structure-based method allowed us to predict the ligand binding mode and to identify the most important interactions between ligand and amino acid side chains in the binding pocket. This information, taken from 3D structure, can be used for modification and optimization of a lead compound, in such way as to avoid interactions with undesirable proteins and/or strengthen interactions with protein of interest. All GPCRs for biogenic amines, have negatively charged aspartic acid at the position D3.32 in the binding pocket. This amino acid is involved in important electrostatic interactions with positively charged ligands, because of which we have assumed that it will form the salt bridge with positively charged imidazoline ligands. Analysis of reverse docking results and receptorligand interactions has confirmed this assumption. Majority of chosen off-target receptors for imidazoline ligands are biogenic amines receptor (adrenergic, dopaminergic and serotonergic), which all have the conserved ASP amino acid at the D3.32 position and form the salt bridge with positively charged imidazoline ligands.

Structural differences between active and inactive states of GPCRs are large at the binding site of the $G$ protein. Therefore, the protocol intended to be used for identification of agonists, partial agonists and antagonists should use active, intermediate and inactive 3D structures, respectively. Since the majority of GPCRs that have been crystalized so far, were crystalized in antagonist-bound, inactive conformation, most of the GPCRs used to prepare this protocol were in their inactive state. Consequently, this protocol is more suitable for the detection of antagonistic activity. The comparison of in silico and in vitro results showed that the compounds which have antagonistic or partial agonistic activity towards the $\alpha_{2}-$ adrenoceptor have good docking scores and are ranked among first $30 \%(\sim 200 / 733)$ screened compounds. Full agonists have low docking scores and are ranked below 400/733. Reverse docking results and ranking, and SP docking scores correlated well with in vitro efficacy. Agonists had low SP docking scores, whereas antagonists had high SP docking scores. On the other hand, between XP docking scores and efficacy we could not observe any correlation whatsoever. This may be due to the penalties this scoring function assigns to the ligands that do not fit well to the used receptor conformation.

In our previous work we have identified novel rilmenidinederived compounds with anticancer potential and without agonistic activity on $\alpha_{2}$-adrenoceptor. We have shown that the most active compound $\mathbf{5 a}$ exhibited a cytotoxic profile, similar to that of rilmenidine, but did not have agonistic activity on $\alpha_{2-}$ adrenoceptors. Moreover, it significantly enhanced the apoptotic response to doxorubicin, and may thus represent an important tool for the development of better adjuvant chemotherapeutic strategies for doxorubicin-insensitive cancers. However, in our previous work we have only focused on agonistic activity $\left(E_{50}\right)$ on $\alpha_{2}$-adrenoceptors. ${ }^{8}$ In this study, we predict its antagonistic potential on these receptors, which should be taken into consideration in further drug design. Moreover, literature data supported our in silico results: idazoxan and efaroxan do have antagonistic effects on $\alpha_{1}$ - 
Running title

adrenoceptors, and these receptors were selected by our protocol as potential off-targets. ${ }^{64,65}$

In recent years, off-target fishing draw attention of many researchers, and some success has been made in the prediction of off-targets for certain compounds. It could be used both for predicting side effects and for drug repurposing ${ }^{66-69}$ The protocol that we have described here could be applied on all the small molecules, for the detection of potential interactions with GPCRs of class A, in the early stage of drug design process. Additionally, this protocol is easily expandable, in a way that it is easy to add novel receptors/subfamily of receptors as soon as the crystal structures and/or 3D models become available. In this study we have used 107 receptors, but taking into consideration the speed of PDB databank growth, we might assume that in a year's time, this number might be considerably higher.

\section{Conclusion}

We have developed and validated a protocol for identification of class A GPCRs, which might be antagonized by imidazoline ligands. We have found potential off-target GPCRs for 3 selected compounds: 5a, efaroxan and idazoxan. Detailed analysis of these off-targets and further in vitro studies could be useful in finding novel indications or understanding side effects of these drugs.

Additionally, this protocol for off-target selection and identification is applicable to all the drug-like small molecules and can be expanded with novel 3D structures of GPCRs. Due to the greater availability of antagonist-bound inactive 3D conformations compared to 3D models of agonist-bound GPCR-G-proteins complexes, this model was prepared for the identification of GPCRs that might be antagonized by ligands used.

In the near future this protocol will be improved, thanks to the rapid development of structural determination methods, growing availability of active GPCR 3D models, as well as an increase in computer power.

\section{Acknowledgements}

KN, MR, HX, NV, JV kindly acknowledge COST action CM1207. MR, HX, NV, KN and TD kindly acknowledge COST action CA18133.

\section{Funding Sources}

This project was supported by the Ministry of Education, Science and Technological Development of the Republic of Serbia, Serbia, Contract \#172033 and \#173001.

\section{References}

1. Ernsberger, P., Meeley, M. P., Mann, J. J. \& Reis, D. J. Clonidine binds to imidazole binding sites as well as $\alpha 2$-adrenoceptors in the ventrolateral medulla. European Journal of Pharmacology 134, 1-13 (1987).

2. Bousquet, P., Feldman, J. \& Schwartz, J. Central cardiovascular effects of alpha adrenergic drugs: differences between catecholamines and imidazolines. J Pharmacol Exp Ther 230 , 232-236 (1984).

3. Chan, C. K. S., Burke, S. L. \& Head, G. A. Contribution of imidazoline receptors and alpha2-adrenoceptors in the rostral ventrolateral medulla to sympathetic baroreflex inhibition by systemic rilmenidine. J. Hypertens. 25, 147-155 (2007).

4. Head, G. A. \& Mayorov, D. N. Imidazoline receptors, novel agents and therapeutic potential. Cardiovasc Hematol Agents Med Chem 4, 17-32 (2006).
5. Nikolic, K. \& Agbaba, D. Imidazoline antihypertensive drugs: selective i(1) -imidazoline receptors activation. Cardiovasc Ther 30, 209-216 (2012).

6. Aceros, H., Farah, G., Noiseux, N. \& Mukaddam-Daher, S Moxonidine modulates cytokine signalling and effects on cardiac cell viability. Eur. J. Pharmacol. 740, 168-182 (2014).

7. Srdic-Rajic, T. et al. Rilmenidine suppresses proliferation and promotes apoptosis via the mitochondrial pathway in human leukemic K562 cells. Eur J Pharm Sci 81, 172-180 (2016).

8. Vucicevic, J. et al. A combined ligand- and structure-based approach for the identification of rilmenidine-derived compounds which synergize the antitumor effects of doxorubicin. Bioorganic \& Medicinal Chemistry 24, 3174-3183 (2016).

9. Piletz, J. E. et al. Imidazoline receptor antisera-selected (IRAS) cDNA: cloning and characterization. DNA Cell Biol. 19, 319-329 (2000).

10. Ernsberger, P. et al. 11-imidazoline receptors. Definition, characterization, distribution, and transmembrane signaling. Ann. N. Y. Acad. Sci. 763, 22-42 (1995).

11. Ernsberger, $P$. The 11-imidazoline receptor and its cellular signaling pathways. Ann. N. Y. Acad. Sci. 881, 35-53 (1999).

12. Sun, Z., Chang, C.-H. \& Ernsberger, P. Identification of IRAS/Nischarin as an 11-imidazoline receptor in PC12 rat pheochromocytoma cells. Journal of Neurochemistry 101, 99108 (2007).

13. Xu, Y., Seet, L. F., Hanson, B. \& Hong, W. The Phox homology $(\mathrm{PX})$ domain, a new player in phosphoinositide signalling Biochem. J. 360, 513-530 (2001).

14. Worby, C. A. \& Dixon, J. E. Sorting out the cellular functions of sorting nexins. Nat. Rev. Mol. Cell Biol. 3, 919-931 (2002).

15. Alahari, S. K. \& Nasrallah, H. A membrane proximal region of the integrin alpha5 subunit is important for its interaction with nischarin. Biochem. J. 377, 449-457 (2004).

16. Felsen, D. et al. Identification, localization and functional analysis of imidazoline and alpha adrenergic receptors in canine prostate. J. Pharmacol. Exp. Ther. 268, 1063-1071 (1994).

17. Hikasa, Y. et al. Identification and characterization of platelet $\alpha 2-$ adrenoceptors and imidazoline receptors in rats, rabbits, cats, dogs, cattle, and horses. European Journal of Pharmacology 720, 363-375 (2013).

18. Molderings, G. J., Moura, D., Fink, K., Bönisch, H. \& Göthert, M. Binding of $[3 \mathrm{H}] \mathrm{clonidine}$ to I1-imidazoline sites in bovine adrenal medullary membranes. Naunyn-Schmiedeberg's Arch Pharmacol 348, 70-76 (1993).

19. Girault, J.-A. Integrating neurotransmission in striatal medium spiny neurons. Adv. Exp. Med. Biol. 970, 407-429 (2012).

20. Greney, $\mathrm{H}$. et al. Coupling of $\mathrm{I}(1)$ imidazoline receptors to the CAMP pathway: studies with a highly selective ligand, benazoline. Mol. Pharmacol. 57, 1142-1151 (2000).

21. Fidom, K. et al. A new crystal structure fragment-based pharmacophore method for $G$ protein-coupled receptors. Methods 71, 104-112 (2015).

22. Klabunde, T., Giegerich, C. \& Evers, A. Sequence-Derived Three-Dimensional Pharmacophore Models for G-ProteinCoupled Receptors and Their Application in Virtual Screening. J. Med. Chem. 52, 2923-2932 (2009).

23. Jenkins, J. L., Bender, A. \& Davies, J. W. In silico target fishing: Predicting biological targets from chemical structure. Drug Discovery Today: Technologies 3, 413-421 (2006).

24. Nikolic, K. et al. Predicting targets of compounds against neurological diseases using cheminformatic methodology. Journal of Computer-Aided Molecular Design 29, 183-198 (2015).

25. Rognan, D. Structure-Based Approaches to Target Fishing and Ligand Profiling. Molecular Informatics 29, 176-187 (2010).

26. Rockey, W. M. \& Elcock, A. H. Structure selection for protein kinase docking and virtual screening: homology models or crystal structures? Curr. Protein Pept. Sci. 7, 437-457 (2006).

27. Chen, Y. Z. \& Zhi, D. G. Ligand-protein inverse docking and its potential use in the computer search of protein targets of a small molecule. Proteins 43, 217-226 (2001).

28. Schomburg, K. T. \& Rarey, M. What is the potential of structurebased target prediction methods? Future Medicinal Chemistry 6 , 1987-1989 (2014).

29. Do, Q.-T. et al. Reverse Pharmacognosy: Identifying Biological Properties for Plants by Means of their Molecule Constituents: Application to Meranzin. Planta Medica 73, 1235-1240 (2007). 
Running title

30. Do, Q.-T. et al. Reverse pharmacognosy: application of selnergy, a new tool for lead discovery. The example of epsilonviniferin. Curr Drug Discov Technol 2, 161-167 (2005).

31. Lee, A., Lee, K. \& Kim, D. Using reverse docking for target identification and its applications for drug discovery. Expert Opinion on Drug Discovery 11, 707-715 (2016).

32. Rasmussen, S. G. F. et al. Crystal structure of the $\beta 2$ adrenergic receptor-Gs protein complex. Nature 477, 549-555 (2011).

33. Carpenter, B., Nehmé, R., Warne, T., Leslie, A. G. W. \& Tate, C. $G$. Structure of the adenosine $A(2 A)$ receptor bound to an engineered G protein. Nature 536, 104-107 (2016).

34. Huang, W. et al. Structural insights into $\mu$-opioid receptor activation. Nature 524, 315-321 (2015)

35. Wingler, L. M., McMahon, C., Staus, D. P., Lefkowitz, R. J. \& Kruse, A. C. Distinctive Activation Mechanism for Angiotensin Receptor Revealed by a Synthetic Nanobody. Cell 176, 479490.e12 (2019).

36. Pieroni, M. et al. Rational Design and Synthesis of Thioridazine Analogues as Enhancers of the Antituberculosis Therapy. J. Med. Chem. 58, 5842-5853 (2015).

37. Halgren, T. A. et al. Glide: A New Approach for Rapid, Accurate Docking and Scoring. 2. Enrichment Factors in Database Screening. Journal of Medicinal Chemistry 47, 1750-1759 (2004).

38. Mysinger, M. M., Carchia, M., Irwin, John. J. \& Shoichet, B. K. Directory of Useful Decoys, Enhanced (DUD-E): Better Ligands and Decoys for Better Benchmarking. J. Med. Chem. 55, 65826594 (2012).

39. OPLS3: A Force Field Providing Broad Coverage of Drug-like Small Molecules and Proteins - Journal of Chemical Theory and Computation (ACS https://pubs.acs.org/doi/10.1021/acs.jctc.5b00864.

40. Shelley, J. C. et al. Epik: a software program for pK molecules. J Comput Aided Mol Des 21, 681-691 (2007).

41. Pándy-Szekeres, G. et al. GPCRdb in 2018: adding GPCR structure models and ligands. Nucleic Acids Res 46, D440D446 (2018).

42. Halgren, T. A. Identifying and Characterizing Binding Sites and Assessing Druggability. J. Chem. Inf. Model. 49, 377-389 (2009).

43. Halgren, T. New Method for Fast and Accurate Binding-site Identification and Analysis. Chemical Biology \& Drug Design 69, 146-148 (2007).

44. Madhavi Sastry, G., Adzhigirey, M., Day, T., Annabhimoju, R. \& Sherman, W. Protein and ligand preparation: parameters, protocols, and influence on virtual screening enrichments. $J$ Comput Aided Mol Des 27, 221-234 (2013).

45. Rostkowski, M., Olsson, M. H., Søndergaard, C. R. \& Jensen, J. $\mathrm{H}$. Graphical analysis of $\mathrm{pH}$-dependent properties of proteins predicted using PROPKA. BMC Struct Biol 11, 6 (2011).

46. Eldridge, M. D., Murray, C. W., Auton, T. R., Paolini, G. V. \& Mee, R. P. Empirical scoring functions: I. The development of a fast empirical scoring function to estimate the binding affinity of ligands in receptor complexes. J. Comput. Aided Mol. Des. 11, 425-445 (1997).

47. Lätti, S., Niinivehmas, S. \& Pentikäinen, O. T. Rocker: Open source, easy-to-use tool for AUC and enrichment calculations and ROC visualization. Journal of Cheminformatics 8, (2016).

48. Clark, R. D. \& Webster-Clark, D. J. Managing bias in ROC curves. J Comput Aided Mol Des 22, 141-146 (2008).

49. Truchon, J.-F. \& Bayly, C. I. Evaluating virtual screening methods: good and bad metrics for the 'early recognition' problem. J Chem Inf Model 47, 488-508 (2007).

50. Sanschagrin, P. C. \& Mainz, D. T. Extra Precision Glide: Docking and Scoring Incorporating a Model of Hydrophobic Enclosure for Protein-Ligand Complexes. (2005).

51. Mishra, C. B., Barodia, S. K., Prakash, A., Senthil Kumar, J. B. \& Luthra, P. M. Novel 8-(furan-2-yl)-3-substituted thiazolo [5,4e][1,2,4] triazolo[1,5-c] pyrimidine-2(3H)-thione derivatives as potential adenosine A2A receptor antagonists. Bioorganic \& Medicinal Chemistry 18, 2491-2500 (2010).

52. Pedregal, C. et al. Development of LC-MS/MS-based receptor occupancy tracers and positron emission tomography radioligands for the nociceptin/orphanin $\mathrm{FQ}$ (NOP) receptor. $J$. Med. Chem. 55, 4955-4967 (2012).

53. Dow, R. L. et al. Design of a Potent CB1 Receptor Antagonist Series: Potential Scaffold for Peripherally-Targeted Agents. ACS Med Chem Lett 3, 397-401 (2012).

54. Bromidge, S. M. et al. 6-[2-(4-Aryl-1-piperazinyl)ethyl]-2H-1,4benzoxazin-3(4H)-ones: dual-acting 5-HT1 receptor antagonists and serotonin reuptake inhibitors. Bioorg. Med. Chem. Lett. 18, 5653-5656 (2008).

55. Witherington, J. et al. Conformationally restricted indolopiperidine derivatives as potent CCR2B receptor antagonists. Bioorg. Med. Chem. Lett. 11, 2177-2180 (2001).

56. Peace, S. et al. Identification of a sulfonamide series of CCR2 antagonists. Bioorganic \& Medicinal Chemistry Letters 20, 3961-3964 (2010)

57. DRUGMATRIX: Alpha-1D adrenergic receptor radioligand binding (ligand: prazosin).

58. Pohjanoksa, K. et al. Alpha2-adrenoceptor regulation of adenylyl cyclase in $\mathrm{CHO}$ cells: dependence on receptor density, receptor subtype and current activity of adenylyl cyclase. Eur. J. Pharmacol. 335, 53-63 (1997).

59. Bradford, M. M. A rapid and sensitive method for the quantitation of microgram quantities of protein utilizing the principle of protein-dye binding. Anal. Biochem. 72, 248-254 (1976).

60. Peltonen, J. M., Pihlavisto, M. \& Scheinin, M. Subtype-specific stimulation of [35S]GTPgammaS binding by recombinant alpha2-adrenoceptors. Eur. J. Pharmacol. 355, 275-279 (1998).

61. Vizi, E. S. et al. Berbanes: a new class of selective alpha 2adrenoceptor antagonists. J. Med. Chem. 30, 1355-1359 (1987).

62. Docherty, J. R., Göthert, M., Dieckhöfer, C. \& Starke, K. Effects of 4-chloro-2-(2-imidazolin-2-ylamino)-isoindoline Hydrochloride (BE 6143) at pre- and postsynaptic alpha-adrenoceptors in rabbit aorta and pulmonary artery. Arzneimittelforschung 32, 1534-1540 (1982).

63. Dardonville, C., Jagerovic, N., Callado, L. F. \& Meana, J. J. Fentanyl derivatives bearing aliphatic alkaneguanidinium moieties: a new series of hybrid molecules with significant binding affinity for $\mu$-opioid receptors and I2-imidazoline binding sites. Bioorganic \& Medicinal Chemistry Letters 14, 491-493 (2004).

64. Berridge, T. L., Doxey, J. C., Roach, A. G. \& Smith, C. F. C. Selectivity profile of the a2-adrenoceptor antagonist efaroxan in relation to plasma glucose and insulin levels in the rat. European Journal of Pharmacology 213, 205-212 (1992).

65. Doxey, J. C., Lane, A. C., Roach, A. G. \& Virdee, N. K. Comparison of the alpha-adrenoceptor antagonist profiles of idazoxan (RX 781094), yohimbine, rauwolscine and corynanthine. Naunyn Schmiedebergs Arch. Pharmacol. 325, 136-144 (1984).

66. Patel, H., Lucas, X., Bendik, I., Günther, S. \& Merfort, I. Target Fishing by Cross-Docking to Explain Polypharmacological Effects. ChemMedChem 10, 1209-1217 (2015).

67. Yang, L. et al. Exploring Off-Targets and Off-Systems for Adverse Drug Reactions via Chemical-Protein Interactome Clozapine-Induced Agranulocytosis as a Case Study. PLoS Computational Biology 7, e1002016 (2011).

68. Verma, N. et al. Identification of gefitinib off-targets using a structure-based systems biology approach; their validation with reverse docking and retrospective data mining. Scientific Reports 6, (2016).

69. Pasznik, P., Rutkowska, E., Niewieczerzal, S., CieleckaPiontek, J. \& Latek, D. Potential off-target effects of betablockers on gut hormone receptors: In silico study including GUT-DOCK-A web service for small-molecule docking. PLOS ONE 14, e0210705 (2019).

Received: ((will be filled in by the editorial staff)) Accepted: ((will be filled in by the editorial staff)) Published online: ((will be filled in by the editorial staff)) 
al.

This article is protected by copyright. All rights reserved. 